\title{
2D Corrugated Magnesium Carboxyphosphonate Materials: Topotactic Transformations and Interlayer "Decoration" with Ammonia
}

Konstantinos D. Demadis, ${ }^{*}{ }^{\dagger}$ Nikos Famelis, $^{\dagger}$ Aurelio Cabeza, ${ }^{\ddagger}$ Miguel A.G. Aranda, ${ }^{\ddagger}$ Rosario M. P. Colodrero, ${ }^{\ddagger}$ and Antonia Infantes-Molina ${ }^{\S}$

${ }^{\dagger}$ Crystal Engineering, Growth and Design Laboratory, Department of Chemistry, University of Crete, Voutes Campus, Crete, GR-71003, Greece

${ }^{\ddagger}$ Departamento de Química Inorgánica, Universidad de Málaga, Campus Teatinos s/n, 29071-Málaga, Spain

${ }^{\S}$ Instituto de Catálisis y Petroleoquímica, CSIC, Cantoblanco, 28049 Madrid, Spain

Supporting Information

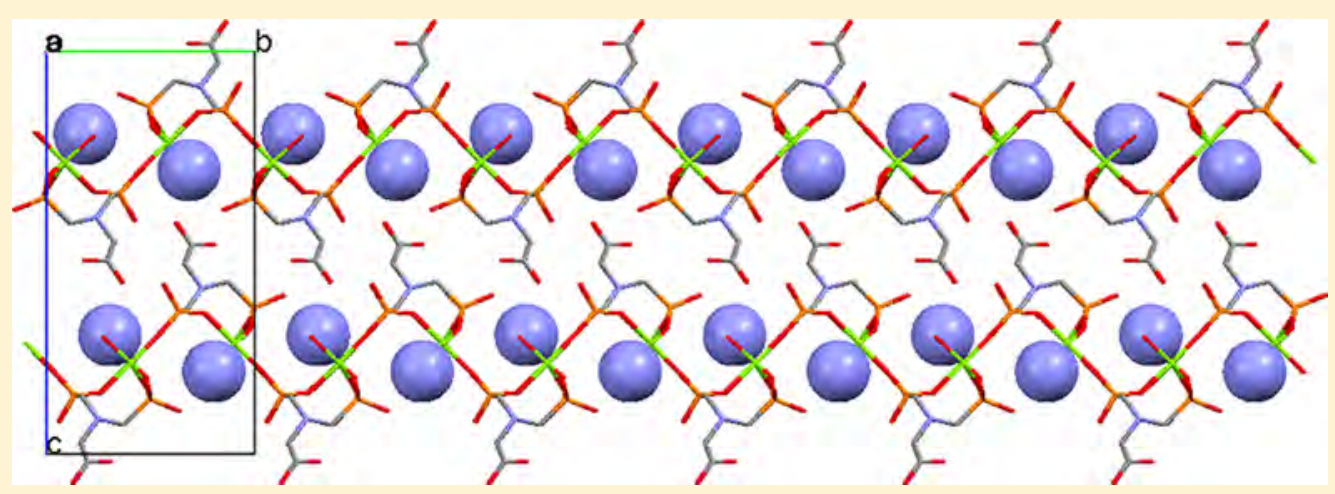

ABSTRACT: In this paper we report the synthesis and structural characterization of the 2D layered coordination polymer $\mathrm{Mg}(\mathrm{BPMGLY})\left(\mathrm{H}_{2} \mathrm{O}\right)_{2}$ (BPMGLY = bis-phosphonomethylglycine, $\left.\left(\mathrm{HO}_{3} \mathrm{PCH}_{2}\right)_{2} \mathrm{~N}(\mathrm{H}) \mathrm{COO}^{2-}\right)$. The $\mathrm{Mg}$ ion is found in a slightly distorted octahedral environment formed by four phosphonate oxygens and two water molecules. The carboxylate group is deprotonated but noncoordinated. This compound is a useful starting material for a number of topotactic transformations. Upon heating at $140{ }^{\circ} \mathrm{C}$ one (of the two) Mg-coordinated water molecule is lost, with the archetype 2D structure maintaining itself. However, the octahedral $\mathrm{Mg}$ in $\mathrm{Mg}(\mathrm{BPMGLY})\left(\mathrm{H}_{2} \mathrm{O}\right)_{2}$ is now converted to trigonal bipyramidal in $\mathrm{Mg}(\mathrm{BPMGLY})\left(\mathrm{H}_{2} \mathrm{O}\right)$. Upon exposure of the monohydrate $\mathrm{Mg}(\mathrm{BPMGLY})\left(\mathrm{H}_{2} \mathrm{O}\right)$ compound to ammonia, one molecule of ammonia is inserted into the interlayer space and stabilized by hydrogen bonding. The $2 \mathrm{D}$ layered structure of the product $\operatorname{Mg}(\mathrm{BPMGLY})\left(\mathrm{H}_{2} \mathrm{O}\right)\left(\mathrm{NH}_{3}\right)$ is still maintained, with $\mathrm{Mg}$ now acquiring a pseudo-octahedral environment. All of these topotactic transformations are also accompanied by changes in hydrogen bonding between the layers.

\section{INTRODUCTION}

An emerging area in the field of metal-organic frameworks is that of metal phosphonates. The latest advances in this rapidly growing discipline have appeared in a book. ${ }^{1}$ (Poly)phosphonate ligands are often envisioned as relatives of (poly)carboxylates. During the last 20 years it has become evident that their coordination/structural chemistry is fundamentally different. As the coordination chemist's "ligand toolbox" becomes wider, richer, and more diverse, there is a conscientious effort to systematize ligand behavior, which will ideally lead to materials design and structure prediction. In the field of metal phosphonate chemistry, it is difficult to achieve predictability of end products, even if the ligand structures are systematically changed. ${ }^{2}$ In this context, we and other researches have undertaken synthetic and structural studies with the following classes of phosphonate ligands: tetraphosph- onates [ethylenediamine-tetrakis(methylenephosphonate), EDTMP; ${ }^{3}$ tetramethylenediamine-tetrakis (methylenephosphonate), TDTMP; ${ }^{4}$ hexamethylenediaminetetrakis(methylenephosphonate), $\left.\mathrm{HDTMP}^{5}\right]$, carboxyphosphonates [hydroxyphosphonoacetate, HPAA; ${ }^{6}$ phosphonoacetate, $\mathrm{PAA}^{7}$ ], various aminomethylenephosphonates [amino-tris(methylenephosphonate), AMP; ${ }^{8}$ 2-hydroxyethyl-amino-bis(methylenephosphonate), HEABMP ${ }^{9}$ ], and unsaturated monophosphonates [vinylphosphonate and phenylvinylphosphonate $\left.{ }^{10}\right]$. Herein, we report the synthesis, structural characterization, topotactic transformations, and ammonia absorption properties of Mg-BPMGLY (BPMGLY = bisphosphonomethylglycine). The ligand BPMGLY belongs to a

Received: May 8, 2012

Published: June 29, 2012 
family of tridentate ligands originating from NTA (a tricarboxylate) and systematically replacing carboxylate moieties by phosphonate ones. In this way, the resulting ligands are PMIDA, BPMGLY, and AMP. These structural changes are shown in Figure 1.
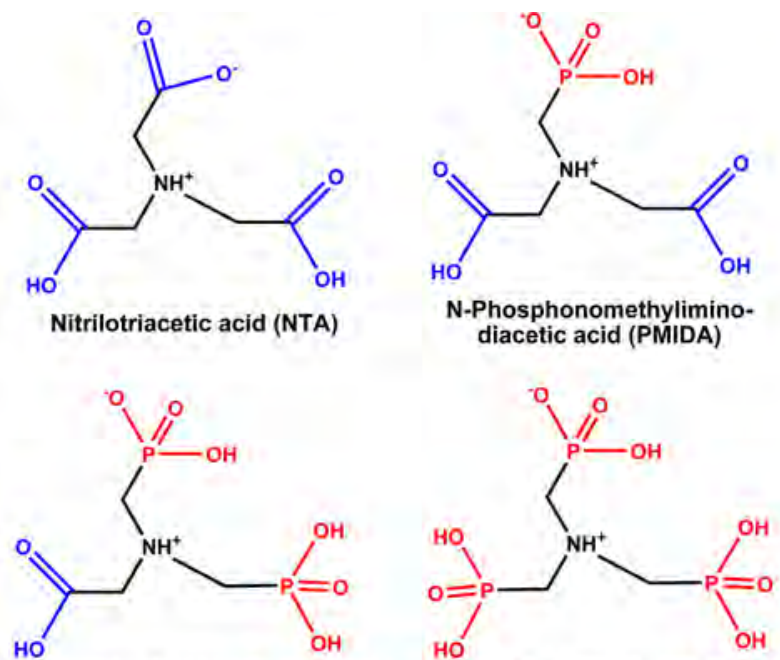

N,N-Bisphosphonometh (BPMGLY)

(AMP)

Figure 1. Schematic structures of four related tripodal ligands in their zwitterionic form with systematically altered moieties in their backbone. Carboxylate (blue) and phosphonate (red) moieties are highlighted appropriately.
Furthermore, the dehydration behavior of $\mathrm{Mg}-\mathrm{BPMGLY}$ is presented along with its ability to absorb/store ammonia. Ammonia storage in nanostructured materials has been a "hot" topic in recent years. ${ }^{5 a, 11}$

\section{EXPERIMENTAL SECTION}

All chemicals used in this study were from commercial sources and used as received.

Syntheses. Synthesis of the Ligand BPMGLY. The ligand was prepared according to a well-established Mannich-type phosphonomethylation process according to published procedures. ${ }^{12}$

Synthesis of $\mathrm{Mg}\left(\mathrm{HO}_{3} \mathrm{PCH}\right)_{2} \mathrm{~N}(\mathrm{H})\left(\mathrm{CH}_{2} \mathrm{COO}\right)\left(\mathrm{H}_{2} \mathrm{O}\right)_{2}(\mathrm{Mg}-$ BPMGLY.2W). A quantity of $\mathrm{MgCl}_{2} \cdot 6 \mathrm{H}_{2} \mathrm{O}(4 \mathrm{mmol})$ and $N, N$ bis(phosphonomethyl)glycine (BPMGLY) were dissolved in $40 \mathrm{~mL}$ of deionized water in a 1:1 molar ratio. The $\mathrm{pH}$ was initially raised by a dilute $\mathrm{NaOH}$ solution to 2.8 . Then the clear, colorless solution was placed in a thick-walled Pyrex bottle and placed in an $85{ }^{\circ} \mathrm{C}$ oven. After overnight heating a crystalline material had precipitated and was isolated by filtration and finally air dried. Typical yields exceed $75 \%$. Single crystals of $\mathbf{M g}-\mathbf{B P M G L Y} \cdot \mathbf{2} \mathbf{W}$ were grown as follows. The filtrate from the previous synthesis was placed again in the oven (85 ${ }^{\circ} \mathrm{C}$ ) and incubated under the same conditions as previously mentioned. Five to six days later the temperature was increased, initially to $115{ }^{\circ} \mathrm{C}$ and gradually within the next $12 \mathrm{~h}$ to $135{ }^{\circ} \mathrm{C}$. The temperature gradient leads to formation of single crystals, suitable for crystallography.

$\mathrm{Mg}\left(\mathrm{HO}_{3} \mathrm{PCH}_{2}\right)_{2} \mathrm{~N}(\mathrm{H})\left(\mathrm{CH}_{2} \mathrm{COO}\right)\left(\mathrm{H}_{2} \mathrm{O}\right)(\mathrm{Mg}-\mathrm{BPMGL} \cdot W)$. Following the thermal study described below, crystalline $\mathbf{M g}-\mathrm{BPMGLY} \cdot \mathbf{W}$ was obtained by heating $\mathbf{M g}-\mathbf{B P M G L Y} \cdot \mathbf{2 W}$ at $140{ }^{\circ} \mathrm{C}$ for $2 \mathrm{~h}$ under static air.

$\mathrm{Mg}\left(\mathrm{HO}_{3} \mathrm{PCH}_{2}\right)_{2} \mathrm{~N}(\mathrm{H})\left(\mathrm{CH}_{2} \mathrm{COO}\right)\left(\mathrm{H}_{2} \mathrm{O}\right)\left(\mathrm{NH}_{3}\right) \quad(\mathrm{Mg}-\mathrm{BPMGL} \cdot \mathrm{W} \cdot \mathrm{N})$. $\mathbf{M g}-\mathbf{B P M G L Y} \cdot \mathbf{2} \mathrm{W}$ was heated under He flow from room temperature to $140{ }^{\circ} \mathrm{C}$ with a heating rate of $10{ }^{\circ} \mathrm{C} \mathrm{min}{ }^{-1}$ in a glass tube. After

Table 1. Crystallographic Data for the Reported Materials

\begin{tabular}{|c|c|c|c|}
\hline phase & $\mathrm{Mg}-\mathrm{BPMGLY} \cdot 2 \mathrm{~W}$ & Mg-BPMGLY·W & $\mathrm{Mg}-\mathrm{BPMGLY} \cdot \mathrm{W} \cdot \mathrm{N}$ \\
\hline empirical formula & $\mathrm{C}_{4} \mathrm{H}_{13} \mathrm{~N}_{1} \mathrm{O}_{10} \mathrm{P}_{2} \mathrm{Mg}$ & $\mathrm{C}_{4} \mathrm{H}_{11} \mathrm{~N}_{1} \mathrm{O}_{9} \mathrm{P}_{2} \mathrm{Mg}$ & $\mathrm{C}_{4} \mathrm{H}_{14} \mathrm{~N}_{2} \mathrm{O}_{9} \mathrm{P}_{2} \mathrm{Mg}$ \\
\hline $\mathrm{fw}\left(\mathrm{g} \cdot \mathrm{mol}^{-1}\right)$ & 320.98 & 302.96 & 320.00 \\
\hline space group & $\mathrm{P} 2_{1} / \mathrm{n}$ & $\mathrm{P} 2_{1} / \mathrm{n}$ & $\mathrm{P} 2_{1} / \mathrm{n}$ \\
\hline$\lambda(\AA)$ & 0.71073 & 1.54060 & 1.54060 \\
\hline$a(\AA)$ & $5.500(6)$ & $5.60160(19)$ & $5.5295(2)$ \\
\hline$b(\AA)$ & $10.292(11)$ & $10.2169(3)$ & $10.3255(3)$ \\
\hline$c(\AA)$ & $20.04(2)$ & $19.8289(7)$ & $20.0000(8)$ \\
\hline$\alpha(\mathrm{deg})$ & 90.00 & 90.00 & 90.00 \\
\hline$\beta(\mathrm{deg})$ & $91.313(19)$ & $94.140(2)$ & $92.303(3)$ \\
\hline$\gamma(\mathrm{deg})$ & 90.00 & 90.00 & 90.00 \\
\hline$V\left(\AA^{3}\right)$ & $1134(2)$ & $1131.87(6)$ & $1140.97(7)$ \\
\hline cryst size $(\mathrm{mm})$ & $0.18 \times 0.09 \times 0.07$ & - & - \\
\hline Z & 4 & 4 & 4 \\
\hline$\rho_{\text {calcd }}\left(\mathrm{g} \cdot \mathrm{cm}^{-3}\right)$ & 1.982 & 1.715 & 1.783 \\
\hline $2 \theta$ range $(\mathrm{deg})$ & $2.03-26.07$ & $4-100$ & $5-90$ \\
\hline data/restrains/params & $2239 / 0 / 164$ & $5410 / 35 / 91$ & $5035 / 35 / 103$ \\
\hline no. of reflns & 8882 & 1173 & 1171 \\
\hline independent reflns $[I>2 \sigma(I)]$ & 1897 & & \\
\hline$R_{\mathrm{wp}}$ & & 0.1432 & 0.0957 \\
\hline$R_{\mathrm{p}}$ & & 0.1053 & 0.0704 \\
\hline$R_{\mathrm{F}}$ & & 0.0575 & 0.0445 \\
\hline GoF, $F^{2}$ & 1.075 & & \\
\hline \multirow[t]{2}{*}{$R$ factor $[I>2 \sigma(I)]$} & $\mathrm{R} 1=0.0322^{a}$ & & \\
\hline & $\mathrm{wR} 2=0.0876^{a}$ & & \\
\hline \multirow[t]{2}{*}{$R$ factor (all data) } & $\mathrm{R} 1=0.0406^{a}$ & & \\
\hline & $\mathrm{wR} 2=0.0921^{a}$ & & \\
\hline CCDC Reference Code & 729893 & 811892 & 811893 \\
\hline
\end{tabular}


cooling at room temperature, a valve was opened and pure $\mathrm{NH}_{3}$ gas was allowed to diffuse for $1 \mathrm{~h}$. Finally, the sample was cleaned with $\mathrm{He}$ flow at room temperature. Under these conditions, $\mathbf{M g}-$ BPMGLY·W·N was isolated.

Crystallography. Single-Crystal X-ray Crystallography. X-ray diffraction data were collected on a SMART $1 \mathrm{~K}$ CCD diffractometer at $298(2) \mathrm{K}$ with $\mathrm{Mo} \mathrm{K} \alpha(\lambda=0.71073 \AA)$. Relevant information concerning crystal data, intensity collection information, and structure refinement parameters for the structure are provided in Table 1. Several regularly shaped colorless crystals (blocks) were selected and sealed in an airtight vial (to avoid water loss) for single-crystal X-ray data collection. Standard crystallographic methods (direct methods) were used to initially locate the heavier atoms in the structure. Remaining non-hydrogen atoms were located in subsequent difference Fourier maps. Empirical absorption corrections were applied with SADABS. ${ }^{13}$ All atoms were refined anisotropically. Hydrogen atoms were located in the difference Fourier map and refined as well. All computations were performed using the NRCVAX suite of programs. ${ }^{14}$ Atomic scattering factors were taken from a standard source ${ }^{15}$ and corrected for anomalous dispersion.

Structural Characterization from Powder Data. Laboratory X-ray powder diffraction (XRPD) patterns were collected on a PANanalytical X'Pert Pro diffractometer equipped with an X'Celerator detector and a $\mathrm{Ge}(111)$ primary monochromator which yields $\mathrm{Cu} \mathrm{K} \alpha_{1}$ radiation, $\lambda=1.54059 \AA$. The overall measurement time was $\sim 2 \mathrm{~h}$ per pattern to have good statistics over the $6.0-100.0^{\circ}(2 \theta)$ angular range, with $0.017^{\circ}$ step size.

The crystal structure of $\mathbf{M g}-\mathbf{B P M G L Y} \cdot \mathbf{W}$ was refined using that of Mg-BPMGLY·2W as a starting model by the Rietveld method ${ }^{16}$ using the GSAS package ${ }^{17}$ and the EXPGUI graphic interface. ${ }^{18}$ The crystal structure was derived by two different refinements that converged to the same final structure. As BPMGLY·2W has two crystallographically independent water molecules, two refinements were carried out by setting the occupation factor of 1 water molecule to zero and allowing the structure to vary. The crystal structure of $\mathbf{M g}-\mathbf{B P M G L Y} \cdot \mathbf{W} \cdot \mathbf{N}$ was refined using that of $\mathbf{M g}-\mathbf{B P M G L Y} \cdot \mathbf{W}$ as a starting model, and the nitrogen atom of the ammonia molecule was located by a difference Fourier map.

For the final refinements of both samples, soft constraints were imposed in order to preserve chemically reasonable geometries for the phosphonate, carboxylate, and amine groups. The soft constrains were as follows: $\mathrm{PO}_{3} \mathrm{C}$ tetrahedron/P-O [1.53(1) $\AA$ ], $\mathrm{P}-\mathrm{C}[1.80(1) \AA]$, $\mathrm{O} \cdots \mathrm{O}[2.55(2) \AA], \mathrm{O} \cdots \mathrm{C}[2.73(2) \AA] ; \mathrm{N}\left(\mathrm{CH}_{2}\right)_{3}$ amine group/N-C $[1.50(1) \AA], \quad \mathrm{C} \cdots \mathrm{C}[2.45(2) \AA]$; carboxylate group $/ \mathrm{C}_{1} \mathrm{H}_{2}-\mathrm{C}_{2} \mathrm{OO}$ group $/ \mathrm{C}_{1}-\mathrm{C}_{2}[1.50(1) \AA], \mathrm{C}_{2}-\mathrm{O}_{\text {carb }}[1.23(1) \AA], \mathrm{O}_{\text {carb }} \mathrm{O}_{\text {carb }}[2.21(2)$ $\AA]$ and $\mathrm{C}_{1} \cdots \mathrm{O}_{\text {carb }}[2.36(2) \AA]$. No attempts to locate the $\mathrm{H}$ atoms were carried out due to the limited quality of the XRPD data. The crystal structures of the two materials have been deposited at the CCDC, and the reference codes and some crystallographic details are given in Table 1. Full details of the crystal structure and refinements are included in the CIF file in the Supporting Information, and the final Rietveld plots are given in the Supporting Information as Figures S1 and S2.

The thermodiffractometric study for $\mathbf{M g}-\mathbf{B P M G L Y} \cdot \mathbf{2 W}$ was carried out using an Anton Paar TTK1200N camera under static air. Data were collected using a Bragg-Brentano configuration with a $\mathrm{Ge}(111)$ primary monochromator and a X'Celerator detector. Sample was heated at selected temperatures from room temperature to $260^{\circ} \mathrm{C}$ with a delay time of $20 \mathrm{~min}$ in order to ensure thermal equilibration. The data range was $8-40^{\circ}(2 \theta)$, step size of $0.017^{\circ}$, and equivalent counting time of $81 \mathrm{~s} /$ step.

Thermal and FT-IR Studies. Thermogravimetric analysis (TGA) and differential thermal analysis (DTA) data were recorded for $\mathbf{M g}-$ BPMGLY·2W on an SDT-Q600 analyzer from TA Instruments. The sample was placed in an open platinum crucible under air flow. Temperature was varied from room tempaerature to $400{ }^{\circ} \mathrm{C}$ at a heating rate of $10^{\circ} \mathrm{C} \cdot \mathrm{min}^{-1}$. Infrared spectra were obtained with an ATR accessory (MIRacle ATR, PIKE Technologies, USA) coupled to a FTIR spectrometer (FT/IR-4100, JASCO, Spain). All spectra were recorded in the $4000-600 \mathrm{~cm}^{-1}$ range at $4 \mathrm{~cm}^{-1}$ resolution, and 50 scans were accumulated.

\section{RESULTS AND DISCUSSION}

FT-IR Spectroscopy. Full FT-IR spectra of the ligand and the three $\mathrm{Mg}$ compounds are given in the Supporting Information, Figure S3. The ligand BPMGLY contains one carboxylate and two phosphonate groups, which can be cleanly followed by FT-IR spectroscopy. In the free ligand the asymmetric $\nu_{\text {as }}\left(\mathrm{C}=\mathrm{O}\right.$ ) stretch appears at $1724 \mathrm{~cm}^{-1}$ (see Figure 2), typical for uncoordinated carboxylic acids. ${ }^{19}$ In $\mathbf{M g}-$

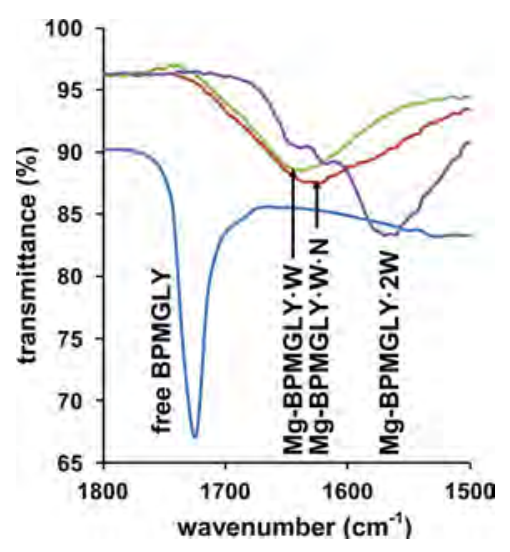

Figure 2. FT-IR spectra of the free ligand BPMGLY, $\mathbf{M g}-$ BPMGLY·2W, Mg-BPMGLY·W, and $\mathbf{M g}-\mathbf{B P M G L Y \cdot W \cdot N}$ in the carboxylate asymmetric stretch region.

BPMGLY $2 \mathrm{~W}$ the $\nu_{\text {as }}(\mathrm{C}=\mathrm{O})$ has shifted to $1564 \mathrm{~cm}^{-1}$. This is a region where metal-coordinated carboxylates appear. ${ }^{20}$ However, upon examination of its crystal structure (see below) the carboxyl group is "free" and not coordinated to $\mathrm{Mg}$. Closer examination reveals that one of the $\mathrm{O}$ atoms of the carboxylate group forms a strong hydrogen bond (2.626 $\AA$ ) with the $-\mathrm{P}-\mathrm{OH}$ group protruding from the layer above. Such an interaction is expected to lower the $\nu_{\mathrm{as}}(\mathrm{C}=\mathrm{O})$ stretch dramatically. Similar observations have been noted before. ${ }^{21}$ The $\mathrm{C}-\mathrm{O}$ bond lengths are 1.262 and $1.236 \AA$, indicating a significant degree of delocalization of the negative charge.

The $\nu_{\text {as }}(\mathrm{C}=\mathrm{O})$ stretch in the spectrum of $\mathbf{M g}-\mathrm{BPMGLY} \cdot \mathbf{W}$ appears at $1641 \mathrm{~cm}^{-1}$, up-shifted from that in $\mathbf{M g}-$ BPMGLY·2W (see Figure 2). This is an indication that the $\mathrm{C}-\mathrm{O} \cdots \mathrm{H}-\mathrm{O}-\mathrm{P}$ hydrogen bond may be weaker. This is corroborated by the slightly longer (C)O $\cdots \mathrm{O}(\mathrm{P})$ distance, $2.651 \AA$. Finally, The $\nu_{\text {as }}(\mathrm{C}=\mathrm{O})$ stretch in the spectrum of $\mathbf{M g}-\mathbf{B P M G L Y} \cdot \mathbf{W} \cdot \mathbf{N}$ appears at $1633 \mathrm{~cm}^{-1}$ (see Figure 2), whereas the $(\mathrm{C}) \mathrm{O} \cdots \mathrm{O}(\mathrm{P})$ distance is found at $2.504 \AA$. Shortening of the (C)O $\cdots \mathrm{O}(\mathrm{P})$ distance should have shifted the vibration frequency to higher wavenumbers, but this is not the case. A possible reason for this "anomaly" may be the presence of a second strong hydrogen bond of the phosphonate $\mathrm{O}$ with the ammonia molecule $\left(\mathrm{H}_{3} \mathrm{~N} \cdots \mathrm{O}(\mathrm{P}) 2.626 \AA\right)$.

As BPMGLY is a zwitterionic ligand, the $\mathrm{N}$ atom is protonated (Figure 1). The weak/broad band at $\sim 2300 \mathrm{~cm}^{-1}$ is assigned to the $\mathrm{N}-\mathrm{H}^{+}$moiety. This remains unchanged in Mg-BPMGLY·2W because the $\mathrm{N}$ atom does not participate in $\mathrm{Mg}$ coordination but remains protonated. The region 850$1250 \mathrm{~cm}^{-1}$ is rich in bands, which are mainly assigned to the phosphonate moieties. These appear altered in intensity and position in the material $\mathbf{M g}-\mathbf{B P M G L Y} \cdot \mathbf{2 W}$. Finally, broad and weak $\mathrm{O}-\mathrm{H}$ stretching vibrations are found at 3560 and 3483 
$\mathrm{cm}^{-1}$ and assigned to $\mathrm{Mg}$-coordinated hydrogen-bonded water molecules. $^{22}$

Thermal Behavior. Figure 3 displays the weight loss curve for $\mathbf{M g}$-BPMGLY·2W at relatively low temperature, which

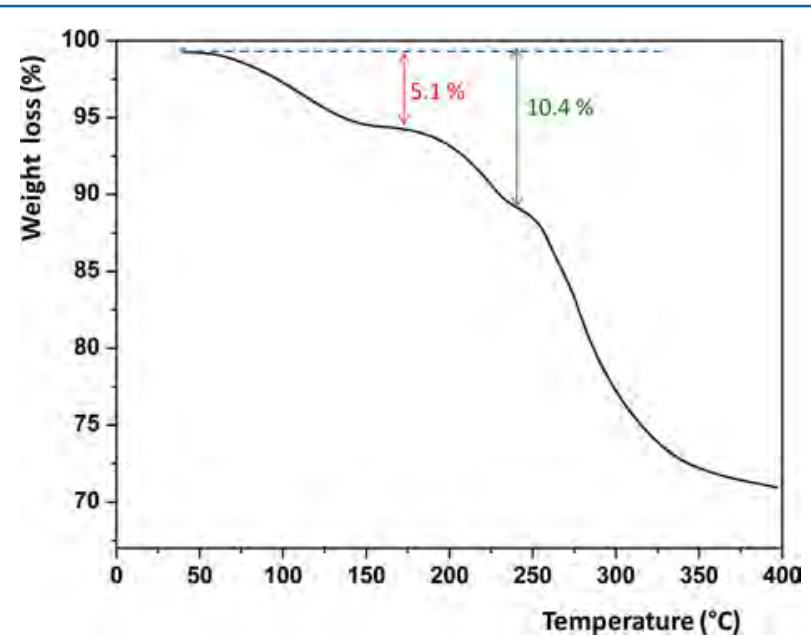

Figure 3. TGA data for Mg-BPMGLY·2W. Two weight-loss steps due to water release are highlighted.

shows three main steps. The theoretical weight loss for one water molecule, $5.32 \mathrm{wt} \%$, agrees well with the measured value up to $160{ }^{\circ} \mathrm{C}$, $5.11 \mathrm{wt} \%$. A second weight loss, $5.25 \mathrm{wt} \%$, is evident in the $190-240{ }^{\circ} \mathrm{C}$ range, which is due to release of the second water molecule. Above $250{ }^{\circ} \mathrm{C}$, the thermal decomposition/burning of $\mathbf{M g}-\mathbf{B P M G L Y} \cdot \mathbf{2 W}$ starts. These last two processes are partly overlapped.

A thermodiffractometric study for $\mathbf{M g}-\mathbf{B P M G L Y} \cdot \mathbf{2 W}$ was carried out to characterize the water loss, see Figure 4. As it will

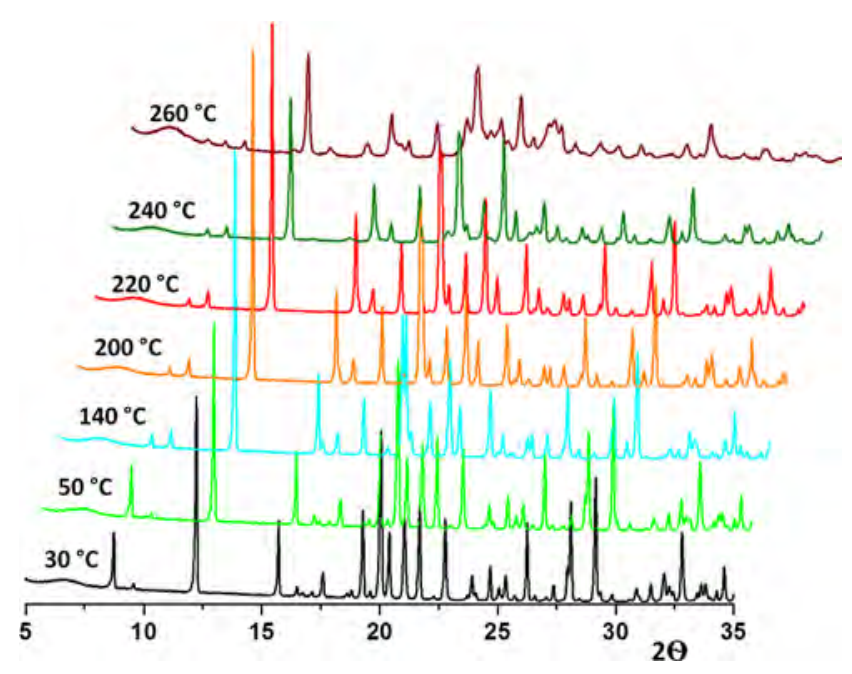

Figure 4. Thermodiffractometric study for Mg-BPMGLY·2W.

be described in the structural section below, the water molecules are directly bonded to the magnesium cations. Hence, it is very remarkable that the water loss in $\mathbf{M g}-$ BPMGLY·2W is accompanied by minor structural changes but the framework is maintained as the overall shape of the pattern changes little between room temperature and $220{ }^{\circ} \mathrm{C}$. This thermal behavior leads us to study the crystal structure of $\mathbf{M g}-$ BPMGLY·W, which was obtained by heating at $140{ }^{\circ} \mathrm{C}$ for $2 \mathrm{~h}$.
This monohydrate phase is stable up to approximately $200{ }^{\circ} \mathrm{C}$. Above $220{ }^{\circ} \mathrm{C}$, the second water molecule is lost and new diffraction peaks appear together with a progressive amorphization of the solid. Crystalline anhydrous, Mg-BPMGLY, could not be isolated as single phase, as organic moiety decomposition also takes place.

Crystal Structures. Structure of $M g-B P M G L Y \cdot 2 W$. The crystal structure was determined from single-crystal data. The overall structure can be envisioned as a 2D layered motif. Each individual layer is formed by $\mathrm{Mg}-\mathrm{O}$ (phosphonate) bonds, forming 16-membered rings (see Figure 5).

The $-\mathrm{COO}^{-}$moiety is deprotonated and noncoordinating. It is extended into the interlayer region (above and below each layer), forming a corrugated motif, Figure 6. The $\mathrm{O}-\mathrm{C}-\mathrm{O}$ moiety participates in a triad of strong interlayer hydrogen bonds that holds the layers together. There is a hydrogen bond $(2.626 \AA)$ between $(\mathrm{C}) \mathrm{O}_{9}$ and the $\mathrm{P}_{2}-\mathrm{O}_{8}-\mathrm{H}$ group of the neighboring layer, Figures $5 \mathrm{C}$ and 6 . There is a second hydrogen-bonding interaction $(2.534 \AA$ ) between the oxygen of the $\mathrm{C}_{4}-\mathrm{O}_{10}$ group and the $-\mathrm{P}_{1}-\mathrm{O}_{1}$ moiety of a neighboring layer. Finally, a hydrogen-bonding interaction forms between the oxygen of the $\mathrm{C}_{4}-\mathrm{O}_{10}$ group and a $\mathrm{Mg}$-coordinated water $(2.708 \AA)$. This network of the above H-bonding triad holds the layers together. There are also a number of intralayer hydrogen bonds in which the Mg-bound waters participate: (w) $\mathrm{O}_{4} \cdots \mathrm{O}_{2} \mathrm{P}_{1} 2.969 \AA \AA$; (w) $\mathrm{O}_{5} \cdots \mathrm{O}_{7} \mathrm{P}_{2} 3.056 \AA$; (w) $\mathrm{O}_{5} \cdots \mathrm{O}_{8} \mathrm{P}_{2}$ $3.007 \AA$; and $(\mathrm{w}) \mathrm{O}_{5} \cdots \mathrm{O}_{4}(\mathrm{w}) 2.534 \AA$. Finally, the protonated $\mathrm{N}-\mathrm{H}^{+}$group forms a hydrogen bond with the Mg-bound $\mathrm{O}_{3}\left(\mathrm{P}_{1}\right)$ moiety, $2.771 \AA$. The layers lie parallel to the $a b$ plane, Figure 6.

The coordination geometry of the $\mathrm{Mg}$ center is nearly octahedral, Figure 7. The greatest deviations from orthogonality concern the water ligands with the angle between them being $80.70^{\circ}$, a fact certainly related to the hydrogen-bonding interaction between them that makes the $(\mathrm{w}) \mathrm{O}-\mathrm{Mg}-\mathrm{O}(\mathrm{w})$ more acute.

Structure of $M g-B P M G L Y \cdot W$. When one of the Mgcoordinated water molecules is removed, the coordination geometry of $\mathrm{Mg}$ changes from octahedral to trigonal bipyramidal. $\mathrm{Mg}-\mathrm{O}(\mathrm{P})$ bond distances range from 1.905 to $2.172 \AA$. The $\mathrm{Mg}-\mathrm{O}\left(\mathrm{H}_{2} \mathrm{O}\right)$ length shortens to $1.955 \AA$. These features are shown in Figure 8, left.

This dramatic change in the coordination geometry of $\mathrm{Mg}$ in Mg-BPMGLY·W does not significantly impact the $2 \mathrm{D}$ layered structure, see Figure 8, right. The same 16-membered rings (like in the case of $\mathbf{M g}-\mathbf{B P M G L Y} \cdot \mathbf{2 W}$ ) are formed. The coordination mode of the ligand BPMGLY remains the same. It acts as a bidentate chelate through two phosphonate oxygens (from different phosphonate groups). Then, a second phosphonate oxygen forms an intralayer bridge with a $\mathrm{Mg}$ ion. Therefore each ligand coordinates to four Mg centers.

The carboxylate group remains deprotonated and noncoordinating. It is protruding into the interlayer region (above and below each layer), forming a corrugated motif, Figure 8, right. The $\mathrm{O}-\mathrm{C}-\mathrm{O}$ moiety, just like in Mg-BPMGLY·2W, participates in three intralayer hydrogen bonds that hold the layers together. There is a hydrogen bond $(2.651 \AA)$ between (C) $\mathrm{O}_{9}$ and the $\mathrm{P}_{2}-\mathrm{O}_{8}-\mathrm{H}$ group of the neighboring layer. There is a second strong hydrogen-bonding interaction $(2.368$ $\AA$ ) between the oxygen of the $\mathrm{C}_{4}-\mathrm{O}_{10}$ group and the $-\mathrm{P}_{1}-\mathrm{O}_{1}$ moiety of a neighboring layer. Finally, a hydrogen bond exists between the oxygen of the $\mathrm{C}_{4}-\mathrm{O}_{10}$ group and a $\mathrm{Mg}$ coordinated water $(2.978 \AA)$. There are also a number of 


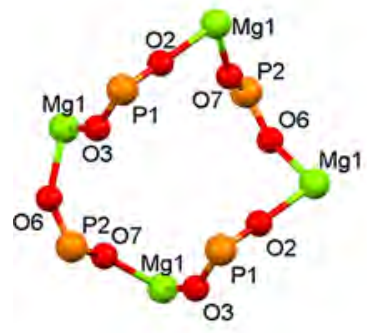

A

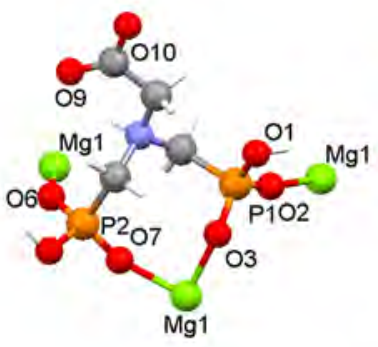

B

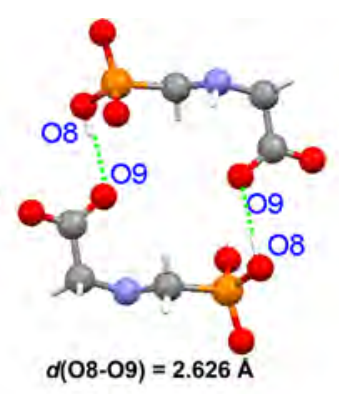

C

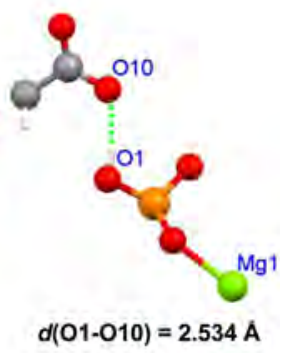

D

Figure 5. $\mathrm{Mg}-\mathrm{O}$ (phosphonate) bonds forming 16-membered rings (A), coordination mode of the ligand BPMGLY in Mg-BPMGLY·2W (B), dyad of $\mathrm{C}-\mathrm{O}_{9} \cdots \mathrm{H}-\mathrm{O}_{8}-\mathrm{P}$ hydrogen bonds holding the layers together $(\mathrm{C})$, and single $\mathrm{C}-\mathrm{O}_{10} \cdots \mathrm{H}-\mathrm{O}_{1}-\mathrm{P}$ hydrogen bond (D).

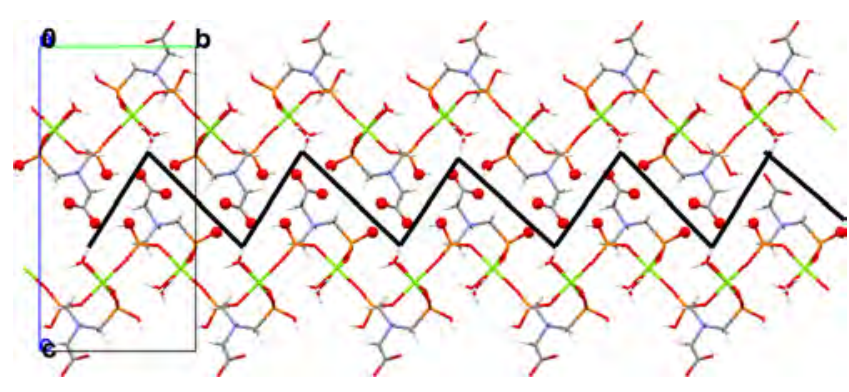

Figure 6. Partial view of two neighboring layers in the crystal structure of Mg-BPMGLY·2W along the $a$ axis. Oxygens from the carboxylate and phosphonate groups which hold the layers together by $\mathrm{H}$ bonding are highlighted as red spheres. Zigzag line separating the two layers is added to aid the reader.

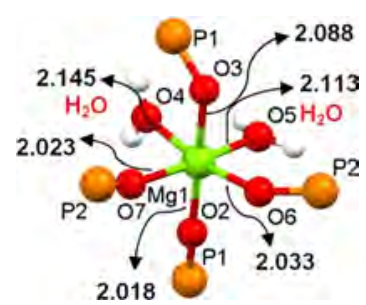

Figure 7. Coordination environment of $\mathrm{Mg}$ in the structure of $\mathrm{Mg}-$ BPMGLY·2W. Bond distances are shown in Angstroms.

intralayer hydrogen bonds in which the $\mathrm{Mg}$-bound water participates: (w) $\mathrm{O}_{4} \cdots \mathrm{O}_{2} \mathrm{P}_{1} 3.008 \AA$; $\mathrm{P}_{2} \mathrm{O}_{7} \cdots \mathrm{O}_{2} \mathrm{P}_{1} 2.849 \AA$; (w) $\mathrm{O}_{5} \cdots \mathrm{O}_{8} \mathrm{P}_{2} 3.007 \AA ; \mathrm{P}_{1} \mathrm{O}_{3} \cdots \mathrm{O}_{6} \mathrm{P}_{2} 2.926 \AA ; \mathrm{P}_{1} \mathrm{O}_{3} \cdots \mathrm{O}_{2} \mathrm{P}_{1} 2.407$ $\AA ; \mathrm{P}_{2} \mathrm{O}_{8} \cdots \mathrm{O}_{7} \mathrm{P}_{2} 2.497 \AA$; and $\mathrm{P}_{2} \mathrm{O}_{6} \cdots \mathrm{O}_{7} \mathrm{P}_{2} 2.567 \AA$. Finally, the protonated $\mathrm{N}-\mathrm{H}^{+}$group forms a hydrogen bond with the $\mathrm{Mg}$ bound $\mathrm{O}_{3}\left(\mathrm{P}_{1}\right)$ moiety, $2.900 \AA$.
Structure of $\mathbf{M g}-\mathbf{B P M G L} \boldsymbol{Y} \cdot \boldsymbol{W} \cdot \boldsymbol{N}$. The $-\mathrm{COOH}$ moiety in the structure of $\mathbf{M g}-\mathbf{B P M G L Y} \cdot \mathbf{W} \cdot \mathbf{N}$ is deprotonated and noncoordinating, as in previous structures. It is extended into the interlayer region (above and below each layer) forming a corrugated motif, Figure 9. The interlayer hydrogen-bonding motif is very similar to that in $\mathbf{M g}-\mathbf{B P M G L Y} \cdot \mathbf{W} \cdot \mathbf{N}$. Its carbonyl moiety $\left(\mathrm{C}_{4}=\mathrm{O}_{9}\right)$ participates in a strong intralayer hydrogen bond $(2.504 \AA)$ with the $\mathrm{P}_{2}-\mathrm{O}_{8}-\mathrm{H}$ group of the neighboring layer. A second interlayer strong hydrogenbonding interaction is found between $\mathrm{O}_{10}$ of the carboxylate group and the $-\mathrm{P}_{1}-\mathrm{O}_{1}$ moiety of a neighboring layer (2.394 $\AA$ ). This H-bonding pair holds the layers together. There are also a number of intralayer hydrogen bonds involving the $\mathrm{Mg}$ bound water molecule and the $\mathrm{NH}_{3}$ host: (w) $\mathrm{O}_{4} \cdots \mathrm{O}_{2} \mathrm{P}_{1} 2.969$ $\AA ; \mathrm{N}_{5} \cdots \mathrm{O}_{2} \mathrm{P}_{1} 2.931 \AA$; $\mathrm{N}_{5} \cdots \mathrm{O}_{8} \mathrm{P}_{2} 2.626 \AA$; and $\mathrm{N}_{5} \cdots \mathrm{O}_{4}(\mathrm{w}) 2.461$ $\AA$. Finally, the protonated $\mathrm{N}-\mathrm{H}^{+}$group forms a hydrogen bond with the Mg-bound $\mathrm{O}_{3}\left(\mathrm{P}_{1}\right)$ moiety, $2.817 \AA$.

The coordination geometry of the $\mathrm{Mg}$ center in $\mathbf{M g}-$ BPMGLY $\cdot \mathbf{W} \cdot \mathbf{N}$ is distorted octahedral, Figure 10 . The angle distortions are greater than those in $\mathbf{M g}-\mathbf{B P M G L Y \cdot 2 W}$. For example, the (w) $\mathrm{O}_{4}-\mathrm{Mg}-\mathrm{N}_{5}$ angle is $65.35^{\circ}$, the $(\mathrm{w}) \mathrm{O}_{4}-\mathrm{Mg}-$ $\mathrm{O}_{3}\left(\mathrm{P}_{1}\right)$ angle is $84.94^{\circ}$, and the $\mathrm{N}_{5}-\mathrm{Mg}-\mathrm{O}_{3}\left(\mathrm{P}_{1}\right)$ angle is $99.81^{\circ}$.

The series of events, dehydration (removal of one $\mathrm{Mg}$ coordinated water molecule) of $\mathbf{M g}-\mathrm{BPMGLY} \cdot \mathbf{2 W}$, change in $\mathrm{Mg}$ coordination geometry (from octahedral to trigonal bipyramidal) to yield $\mathbf{M g}-\mathbf{B P M G L Y} \cdot \mathbf{W}$, insertion of one ammonia molecule to give $\mathbf{M g}-\mathbf{B P M G L Y} \cdot \mathbf{W} \cdot \mathbf{N}$, and finally reversion to (pseudo)octahedral geometry, leaves the $2 \mathrm{D}$ layered structure almost intact. This is certainly due to the presence of several moieties capable of hydrogen bonding. Proof for the fact that the structure is not substantially disturbed by all these structural changes comes from the comparison of the axes lengths $a, b$, and $c$, see Figure 11. There

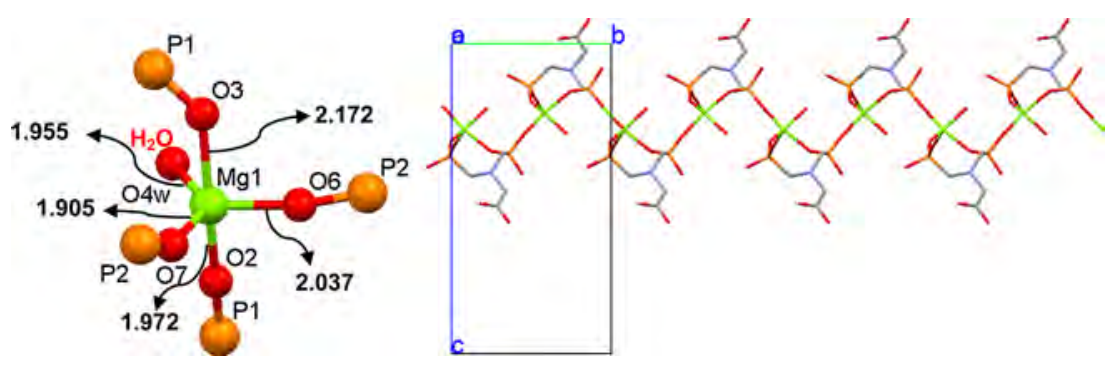

Figure 8. Coordination environment of trigonal bipyramidal $\mathrm{Mg}$ in the structure of $\mathbf{M g}-\mathbf{B P M G L Y} \cdot \mathbf{W}$ (left). Bond distances are shown in Angstroms. View of one layer down the $a$ axis (right). 


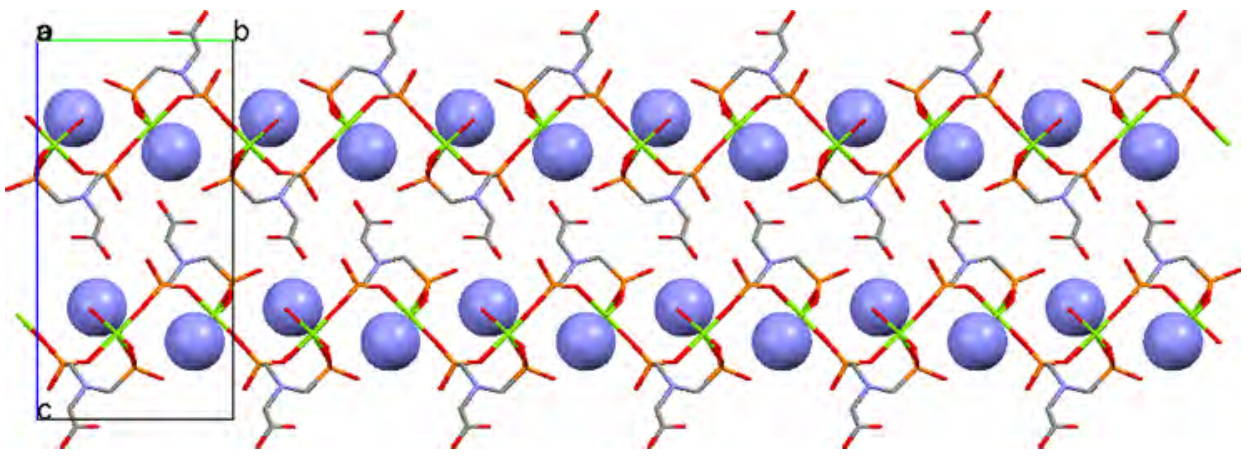

Figure 9. Partial view of two neighboring layers in the crystal structure of $\mathbf{M g}-\mathbf{B P M G L Y} \cdot \mathbf{W} \cdot \mathbf{N}$ along the $a$ axis. Ammonia molecules are depicted as exaggerated blue spheres.

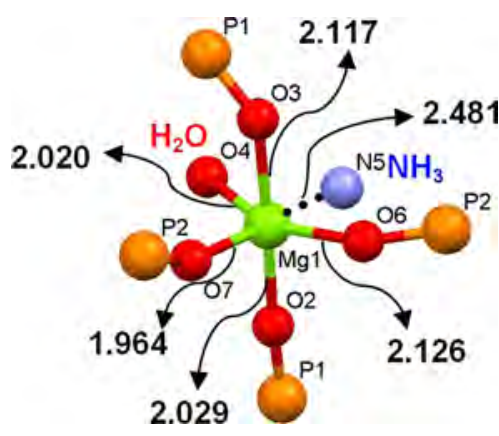

Figure 10. Coordination environment of $\mathrm{Mg}$ in the structure of $\mathbf{M g}-$ BPMGLY $\cdot \mathbf{W} \cdot \mathbf{N}$. Bond distances are shown in Angstroms.

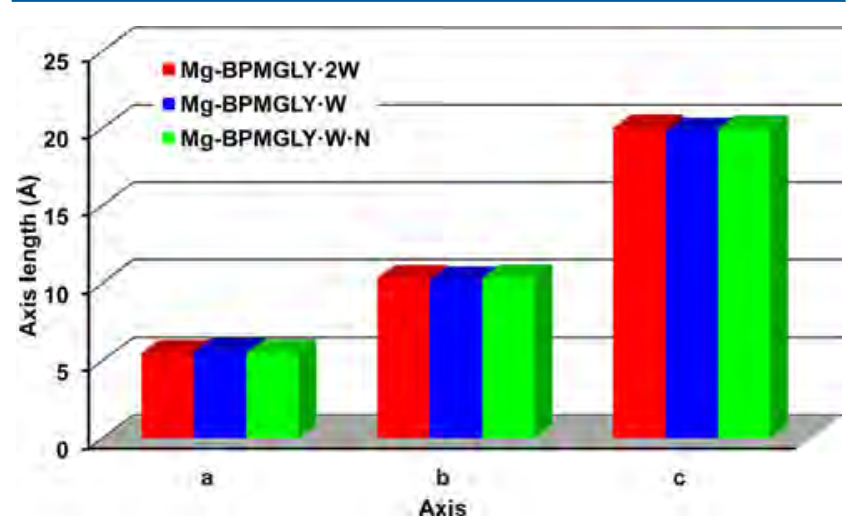

Figure 11. Comparison of the $a$-, $b$-, and $c$-axes lengths in the three compounds.

appears to be very little variation in the lengths, indicating that the BPMGLY ligand forms a very robust $\mathrm{H}$-bonded 2D layered framework. It must be highlighted that the unit cell volume does not shrink on partial dehydration from $\mathbf{M g}-$ BPMGLY·2W to $\mathbf{M g}-\mathbf{B P M G L Y} \cdot \mathbf{W}$, see Table 1 . As a consequence, $\mathbf{M g}-\mathbf{B P M G L Y} \cdot \mathbf{W}$ has a smaller density, $13.5 \%$, than $\mathbf{M g}-\mathbf{B P M G L Y \cdot 2 W}$. Thus, there is space available for gas uptake, and ammonia incorporation slightly expands the volume, see Table 1, likely due to the higher number of $\mathrm{H}$ bonds.

Finally, the bond lengths $(\mathrm{N}-\mathrm{C}, \mathrm{C}-\mathrm{P}, \mathrm{C}-\mathrm{O}, \mathrm{P}-\mathrm{O})$ within the BPMGLY ligand are essentially the same as those in the related ligands NTA, ${ }^{23} \mathrm{PMIDA}^{24}{ }^{24} \mathrm{BMGLY}^{25}$ and AMP. ${ }^{26}$

There exist a small number of metal BPMGLY crystal structures in the literature. Some of them are molecular complexes, e.g., with $\mathrm{Co}(\mathrm{II}),{ }^{27,28} \mathrm{Cr}(\mathrm{III}),{ }^{29}$ and $\mathrm{Ni}(\mathrm{II}),{ }^{30}$ in which all three functional groups (carboxylate, phosphonate, and amine) are coordinated to the metal ion creating chelating rings. Homoleptic transition metal-based multidimensional solids include $\mathrm{Zn}_{2}$ (BPMGLY) ( $\mathrm{Zn}$ is tetrahedral in this case $)^{12}$ and $\left\{\left[\mathrm{NH}_{3}\left(\mathrm{CH}_{2}\right)_{3} \mathrm{NH}_{3}\right]\left(\mathrm{NH}_{4}\right)_{4}\right\}[\mathrm{Ni}($ BPMGLY)$\left.\left(\mathrm{H}_{2} \mathrm{O}\right)\right]_{2} \cdot{ }^{30}$ Also, there has been a report on compounds that contain an ancillary ligand, $\mathrm{Co}_{3}\left(\right.$ BPMGLY) ${ }_{2}$ $\left(\mathrm{H}_{2} \mathrm{O}\right)_{4}(\text { bipy })_{2} \cdot 11 \mathrm{H}_{2} \mathrm{O}$ and $\mathrm{Zn}_{5}(\text { BPMGLY })_{2}(\text { bipy })_{2} \cdot 9 \mathrm{H}_{2} \mathrm{O}$ (bipy $=4,4^{\prime}$-bipyridine). ${ }^{31}$ Lastly, lanthanide-based BPMGLY frameworks have been reported. These include [Ln$($ BPMGLY $)] \cdot x \mathrm{H}_{2} \mathrm{O}(\mathrm{Ln}=\mathrm{Nd}, x=0.75 ; \mathrm{Eu}, x=0.70),{ }^{32}$ $\left[\mathrm{Ln}(\right.$ BPMGLY $\left.)\left(\mathrm{H}_{2} \mathrm{O}\right)\right]\left(\mathrm{Ln}=\mathrm{Y}^{3+}, \mathrm{La}^{3+}, \mathrm{Pr}^{3+}, \mathrm{Nd}^{3+}, \mathrm{Sm}^{3+}, \mathrm{Eu}^{3+}\right.$, $\mathrm{Gd}^{3+}, \mathrm{Tb}^{3+}, \mathrm{Dy}^{3+}, \mathrm{Ho}^{3+}$, and $\left.\mathrm{Er}^{3+}\right),{ }^{33}$ and La(BPMGLY)$\left(\mathrm{H}_{2} \mathrm{O}\right)_{2} \cdot \mathrm{H}_{2} \mathrm{O}{ }^{34}$ In most of the above structures the $\mathrm{N}$ atom of the BPMGLY ligand is protonated, thus noncoordinating, just like in the three $\mathrm{Mg}$ structures described herein.

A short discussion on the $\mathrm{Mg} \cdots \mathrm{NH}_{3}$ interaction is warranted. The $\mathrm{Mg}-\mathrm{N}$ distance is $2.48(2) \AA$. It is worth comparing this to some similar $\mathrm{Mg}-\mathrm{N}$ (ammonia) distances from the literature. For example, the $\mathrm{Mg}-\mathrm{N}$ (ammonia) distance in diammine magnesium diazide, $\operatorname{Mg}\left(\mathrm{NH}_{3}\right)_{2}\left(\mathrm{~N}_{3}\right)_{2}$, is 2.209(4) $\AA^{35}$ The analogous distance in a series of diammine magnesium halides $\mathrm{Mg}\left(\mathrm{NH}_{3}\right)_{2}(\mathrm{X})_{2}$ is $2.137(2) \AA^{36}$ In the compound $\mathrm{Mg}$ $\left(\mathrm{BH}_{4}\right)_{2} \cdot 2 \mathrm{NH}_{3}$ the $\mathrm{Mg}-\mathrm{N}($ ammonia) distances are $2.149(5)$ and $2.030(5) \AA^{37}$ The $\mathrm{N}$ atom of the ammonia molecule $\left(\mathrm{N}_{5}\right)$ forms two strong and one weak interactions with surrounding atoms, see Figure 12.

The limited quality of the powder diffraction data makes the structural discussion about the ammonia environment difficult. However, two arguments must be taken into account: the close to octahedral $\mathrm{O}-\mathrm{Mg} \cdots \mathrm{N}$ angles and the presence of a not extremely long $\mathrm{Mg} \cdots \mathrm{N}$ distance. Both point toward the presence of an ammonia molecule (not ammonium cation),

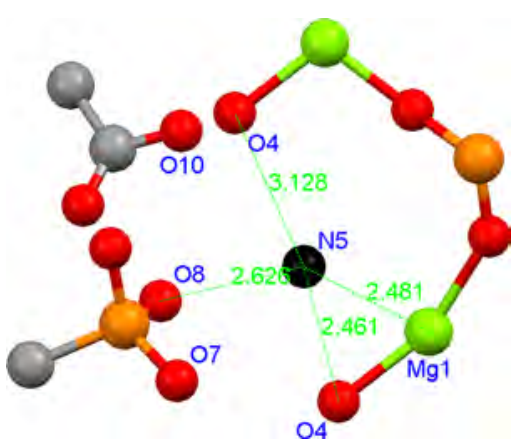

Figure 12. Environment of the $\mathrm{N}$ atom (black sphere) from the intercalated ammonia molecule. Distances are indicated in Angstroms. 
which interacts by its lone pair with the magnesium cation. The three closest oxygen atoms $\left(\mathrm{O}_{4}, \mathrm{O}_{4}{ }^{\prime}\right.$, and $\left.\mathrm{O}_{8}\right)$, see Figure 12, stabilize the ammonia molecule through $\mathrm{N}-\mathrm{H}^{\cdots} \mathrm{O}$ hydrogen bonds, two being quite strong $\left(d\left(\mathrm{~N}_{5} \cdots \mathrm{O}_{4}\right)=2.461 \AA\right.$ and $\left.d\left(\mathrm{~N}_{5} \cdots \mathrm{O}_{8}\right)=2.626 \AA\right)$ and the third being weaker $\left(d\left(\mathrm{~N}_{5} \cdots \mathrm{O}_{4}{ }^{\prime}\right)\right.$ $=3.128 \AA$ ).

\section{CONCLUSIONS}

In this paper we reported the synthesis and structural characterization of the $2 \mathrm{D}$ coordination polymer $\mathbf{M g}-$ BPMGLY·2W. This compound can be a useful starting material for a number of topotactic transformations. For example, upon heating at $140{ }^{\circ} \mathrm{C}$ one (of the two) $\mathrm{Mg}$ coordinated water molecule is lost, with the archetype 2D structure maintaining itself. However, the octahedral $\mathrm{Mg}$ in $\mathbf{M g}-\mathrm{BPMGLY} \cdot \mathbf{2 W}$ is now converted to trigonal bipyramidal in $\mathbf{M g}$-BPMGLY·W. Upon exposure of the monohydrate $\mathbf{M g}-$ BPMGLY'W compound to ammonia, one molecule of ammonia is inserted into the interlayer space and stabilized by hydrogen bonding. The $2 \mathrm{D}$ layered structure of the product $\mathbf{M g}-\mathbf{B P M G L Y} \cdot \mathbf{W} \cdot \mathbf{N}$ is still maintained, with $\mathrm{Mg}$ now acquiring a pseudo-octahedral environment. All of these topotactic transformations are also accompanied by changes in hydrogen bonding between the layers.

\section{ASSOCIATED CONTENT}

\section{S Supporting Information}

Rietveld plots for $\mathbf{M g}-\mathbf{B P M G L Y} \cdot \mathbf{W}$ and $\mathbf{M g}-\mathbf{B P M G L Y} \cdot \mathbf{W} \cdot \mathbf{N}$; FT-IR spectra and crystallographic cif files for $\mathbf{M g}-$ BPMGLY·2W, Mg-BPMGLY·W, and $\mathbf{M g}-\mathbf{B P M G L Y \cdot W \cdot N}$. This material is available free of charge via the Internet at http://pubs.acs.org.

\section{AUTHOR INFORMATION}

\section{Corresponding Author}

*E-mail: demadis@chemisry.uoc.gr.

\section{Notes}

The authors declare no competing financial interest.

\section{ACKNOWLEDGMENTS}

The work at Heraklion was supported by a grant from the Research Committee of the University of Crete (ELKE, KA 2573) and at Malaga by the MAT2010-15175 research grant which is cofunded by FEDER.

\section{REFERENCES}

(1) Metal phosphonate chemistry: From synthesis to applications, Clearfield, A., Demadis, K. D., Eds.; The Royal Society of Chemistry: London, 2012.

(2) Demadis, K. D.; Katarachia, S. D.; Raptis, R. G.; Zhao, H.; Baran, P. Cryst. Growth Des. 2006, 6, 836-838.

(3) Demadis, K. D.; Barouda, E.; Stavgianoudaki, N.; Zhao, H. Cryst. Growth Des. 2009, 9, 1250-1253.

(4) (a) Demadis, K. D.; Barouda, E.; Zhao, H.; Raptis, R. G. Polyhedron 2009, 28, 3361-3367. (b) Ying, S.-M.; Zeng, X.-R.; Fang, X.-N.; Li, X.-F.; Liu, D.-s. Inorg. Chim. Acta 2006, 359, 1589-1593.

(c) Vivani, R.; Costantino, F.; Costantino, U.; Nocchetti, M. Inorg. Chem. 2006, 45, 2388-2390.

(5) (a) Colodrero, R. M. P.; Cabeza, A.; Olivera-Pastor, P.; InfantesMolina, A.; Barouda, E.; Demadis, K. D.; Aranda, M. A. G. Chem.Eur. J. 2009, 15, 6612-6618. (b) Colodrero, R. M. P.; Olivera-Pastor, P.; Losilla, E. R.; Aranda, M. A. G.; Papadaki, M.; McKinlay, A.; Morris, R. E.; Demadis, K. D.; Cabeza, A. Dalton Trans. 2012, 41, 4045-4051. (c) Zheng, G.-L.; Ma, J.-F.; Yang, J. J. Chem. Res. 2004,
387-388. (d) Constantino, F.; Bataille, T.; Audebrand, N.; Le Fur, E.; Sangregorio, C. Cryst. Growth Des. 2007, 7, 1881-1888.

(6) (a) Demadis, K. D.; Papadaki, M.; Raptis, R. G.; Zhao, H. J. Solid State Chem. 2008, 181, 679-683. (b) Demadis, K. D.; Papadaki, M.; Raptis, R. G.; Zhao, H. Chem. Mater. 2008, 20, 4835-4846. (c) Demadis, K. D.; Papadaki, M.; Aranda, M. A. G.; Cabeza, A.; Olivera-Pastor, P.; Sanakis, Y. Cryst. Growth Des. 2010, 10, 357-364. (d) Demadis, K. D.; Papadaki, M.; Cisarova, I. ACS Appl. Mater. Interfaces 2010, 2, 1814-1816. (e) Colodrero, R. M. P.; Cabeza, A.; Olivera-Pastor, P.; Rius, J.; Choquesillo-Lazarte, D.; García-Ruiz, J. M.; Papadaki, M.; Demadis, K. D.; Aranda, M. A. G. Cryst. Growth Des. 2011, 11, 1713-1722. (f) Colodrero, R. M. P.; Olivera-Pastor, P.; Cabeza, A.; Papadaki, M.; Demadis, K. D.; Aranda, M. A. G. Inorg. Chem. 2010, 49, 761-768. (g) Fu, R.; Hu, S.; Wu, X. J. Solid State Chem. 2011, 184, 945-952. (h) Zhang, N.; Huang, C.-Y.; Sun, Z.-G.; Liu, L.; Hua, R.-N.; Lu, X.; Tong, F.; Wang, W.-N. Z. Anorg. Allg. Chem. 2010, 636, 449. (i) Dong, D.-P.; Sun, Z.-G.; Tong, F.; Zhu, Y.Y.; Chen, K.; Jiao, C.-Q.; Wang, C.-L.; Li, C.; Wang, W.-N. CrystEngComm. 2011, 13, 3317-3320.

(7) (a) Lodhia, S.; Turner, A.; Papadaki, M.; Demadis, K. D.; Hix, G. B. Cryst. Growth Des. 2009, 9, 1811-1822. (b) Cabeza, A.; Aranda, M. A. G. In Metal phosphonate chemistry: From synthesis to applications; Clearfield, A., Demadis, K. D., Eds.; The Royal Society of Chemistry: London, 2012; Chapter. 4, pp 107-132. (c) Gómez-Alcántara, M. M.; Aranda, M. A. G.; Cabeza, A.; Guagliardi, A.; Mao, J. G.; Clearfield, A. Solid State Sci. 2004, 6, 479-487. (d) Alsobrook, A. N.; AlbrechtSchmitt, T. E. Inorg. Chem. 2009, 48, 11079-11084.

(8) (a) Demadis, K. D.; Katarachia, S. D.; Koutmos, M. Inorg. Chem. Commun. 2005, 8, 254-258. (b) Demadis, K. D.; Katarachia, S. D. Phosphorus Sulfur Silicon 2004, 179, 627-648. (c) Clearfield, A. Curr. Opin. Solid State Mater. Sci. 2002, 6, 495-506. (d) Cabeza, A.; Ouyang, X.; Sharma, C. V. K.; Aranda, M. A. G.; Bruque, S.; Clearfield, A. Inorg. Chem. 2002, 41, 2325-2333. (e) Sharma, C. V. K.; Clearfield, A.; Cabeza, A.; Aranda, M. A. G.; Bruque, S. J. Am. Chem. Soc. 2001, $123,2885-2886$.

(9) (a) Demadis, K. D.; Baran, P. J. Solid State Chem. 2004, 177, 4768-4776. (b) Demadis, K. D.; Stavgianoudaki, N.; Grossmann, G.; Gruner, M.; Schwartz, J. L. Inorg. Chem. 2009, 48, 4154-4164.

(10) (a) Colodrero, R. M. P.; Cabeza, A.; Olivera-Pastor, P.; Choquesillo-Lazarte, D.; Garcia-Ruiz, J. M.; Turner, A.; Ilia, G.; Maranescu, B.; Papathanasiou, K. E.; Demadis, K. D.; Hix, G. B.; Aranda, M. A. G. Inorg. Chem. 2011, 50, 11202-11211. (b) Hix, G. B.; Turner, A.; Vahter, L.; Kariuki, B. M. Microporous Mesoporous Mater. 2007, 99, 62-69.

(11) (a) Zhu, H.; Gu, X.; Yao, K.; Gao, L.; Chen, J. Ind. Eng. Chem. Res. 2009, 48, 5317-5320. (b) Doonan, C. J.; Tranchemontagne, D. J.; Glover, T. G.; Hunt, J. R.; Yaghi, O. M. Nat. Chem. 2012, 2, 235-238. (c) Helminen, J.; Helenius, J.; Paatero, E. J. Chem. Eng. Data 2001, 46, 391-399. (d) Seredych, M.; Bandosz, T. J. J. Colloid Interface Sci. 2008, 324, 25-35.

(12) Mao, J.-G.; Wang, Z.; Clearfield, A. New J. Chem. 2002, 26, $1010-1014$

(13) Sheldrick, G. M. SADABS (Version 2.03) and TWINABS (Version 1.02); University of Göttingen: Germany, 2002.

(14) Gabe, E. J.; Le Page, Y.; Charland, J.-P.; Lee, F. L.; White, P. S. J. Appl. Crystallogr. 1989, 22, 384-387.

(15) International Tables for X-ray Crystallography; Kynoch Press: Birmigham, U.K., 1974; Vol. IV.

(16) Rietveld, H. M. J. Appl. Crystallogr. 1969, 2, 65-71.

(17) Larson A. C. Von Dreele, R. B. General Structure Analysis System (GSAS). Los Alamos National Laboratory Report LAUR 86748, 2004.

(18) Toby, B. H. J. Appl. Crystallogr. 2001, 34, 210-213.

(19) Nakamoto, K. Infrared and Raman Spectra of Inorganic and Coordination Compounds, Theory and Applications in Inorganic Chemistry; Wiley-Interscience: New York, 1997.

(20) (a) Bellamy, L. J. The Infrared Spectra of Complex Molecules; Chapman and Hall: London, 1975. (b) Alpert, N. L.; Keiser, W. E.; Szymanski, H. A. IR: Theory and Practice of Infrared Spectroscopy, 2nd 
ed.; Plenum Press: New York, 1970. (c) Socrates, G. Infrared Characteristic Group Frequencies: Tables and Charts, 2nd ed.; Wiley: Chichester, U.K., 1994.

(21) (a) Demadis, K. D.; Raptis, R. G.; Baran, P. Bioinorg. Chem. Appl. 2005, 3, 119-134. (b) Demadis, K. D.; Sallis, J. D.; Raptis, R. G.; Baran, P. J. Am. Chem. Soc. 2001, 123, 10129-10130.

(22) (a) Lutz, M.; Müller, G. Inorg. Chim. Acta 1995, 232, 189-193.

(b) Kontturi, M.; Kunnas-Hiltunen, S.; Vepsäläinen, J. J.; Ahlgrén, M. Solid State Sci. 2006, 8, 1098-1102. (c) Maclachan, D. J.; Morgan, K. R. J. Phys. Chem. 1992, 96, 3458-3464.

(23) Stanford, R. H., Jr. Acta Crystallogr. 1967, 23, 825-832.

(24) (a) Shkol'nikova, L. M.; Porai-Koshits, M. A.; Dyatlova, N. M.; Yaroshenko, G. F.; Rudomino, M. V.; Kolova, E. K. Zh. Strukt. Khim. 1982, 23, 98-107. (b) Shkol'nikova, L. M.; Porai-Koshits, M. A.; Dyatlova, N. M.; Yaroshenko, G. F.; Rudomino, M. V.; Kolova, E. K. J. Struct. Chem. 1982, 23, 737-746.

(25) Shkol'nikova, L. M.; Masyuk, A. A.; Khizbullin, F. F.; Strunin, B. P.; Sotman, S. S.; Zhadanov, B. V.; Rudomino, M. V.; Dyatlova, N. M. J. Struct. Chem. 1991, 31, 760-768.

(26) Daly, J. J.; Wheatley, P. J. J. Chem. Soc. A 1967, 212-221.

(27) Mateescu, A.; Gabriel, C.; Raptis, R. G.; Baran, P.; Salifoglou, A.

Inorg. Chim. Acta 2007, 360, 638-648.

(28) Mateescu, A.; Raptopoulou, C. P.; Terzis, A.; Tangoulis, V.; Salifoglou, A. Eur. J. Inorg. Chem. 2006, 1945-1956.

(29) Rajendram, C. R. A.; Hoggard, P. E. J. Coord. Chem. 1994, 33, $15-32$.

(30) Ma, K.; Xu, J.; Zhang, L.; Shi, J.; Zhang, D.; Zhu, Y.; Fan, Y.; Song, T. New J. Chem. 2009, 33, 886-892.

(31) Song, J.-L.; Zhao, H.-H.; Mao, J.-G.; Dunbar, K. R. Chem. Mater. 2004, 16, 1884-1889.

(32) Cunha-Silva, L.; Ananias, D.; Carlos, L. D.; Almeida Paz, F. A.; Rocha, J. Z. Kristallogr. 2009, 224, 261-272.

(33) Cunha-Silva, L.; Lima, S.; Ananias, D.; Silva, P.; Mafra, L.; Carlos, L. D.; Pillinger, M.; Valente, A. A.; Almeida Paz, F. A.; Rocha, J. J. Mater. Chem. 2009, 19, 2618-2632.

(34) Tang, S.-F.; Song, J.-L.; Mao, J.-G. Eur. J. Inorg. Chem. 2006, 2011-2019.

(35) Karau, F.; Schnick, W. Z. Anorg. Allg. Chem. 2006, 632, 49-53. (36) Leineweber, A.; Jacobs, H.; Fischer, P.; Bottger, G. J. Solid State Chem. 2001, 156, 487-499.

(37) Soloveichik, G.; Her, J.-H.; Stephens, P. W.; Gao, Y.; Rijssenbeek, J.; Andrus, M.; Zhao, J.-C. Inorg. Chem. 2008, 47, 4290-4298. 